\title{
Frugivorous Flies (Diptera: Lonchaeidae) Hosts in the State of Bahia, Brazil and registers of new bitrophic interactions
}

\author{
O. O. Santos ${ }^{a *}$, M. A. Castellani ${ }^{b}$, M. A. L. Bittencourt', A. A. Moreira and P. C. Strikis $^{c}$ \\ a'Laboratório de Controle Biológico, Departamento de Ciências Agrárias e Ambientais, Universidade Estadual de Santa \\ Cruz - UESC, Rodovia Jorge Amado, Km 16, CEP 45662-900, Ilhéus, BA, Brazil

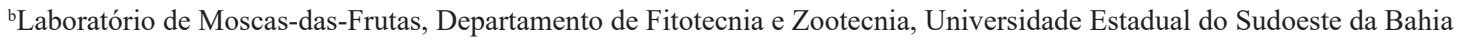 \\ - UESB, Estrada do Bem Querer, Km 04, CEP 45031-900, Vitória da Conquista, BA, Brazil \\ 'Laboratório de Paleontologia, Instituto de Geociências, Universidade de São Paulo - USP, Rua do Lago, 562, \\ Vila Universitária, CEP 05508-080, São Paulo, SP, Brazil \\ *e-mail: olvagro@yahoo.com.br
}

Received: September 5, 2016 - Accepted: March 12, 2017 - Distributed: October 31, 2018

Larvae of Lonchaeidae flies (Tephritoidea) are found in decaying organic material (trunks, branches and leaves), flower buds are attacked by Dasiops frieseni Norrbom \& McAlpine, 1997, damaged fruits as well as ripe and green ones of oranges and passion fruits, all infested by Neosilba zadolicha McAlpine \& Steyskal, 1982 (Strikis et al., 2011). In Brazil three genera of Lonchaeidae have been found: Dasiops Rondani (1856), Neosilba McAlpine (1962) and Lonchaea Fallén (1820). Neosilba and Dasiops are the most important from an economic point of view, once they include the majority of frugivorous flies (Strikis et al., 2011). The main purpose of this work was to extend the knowledge over Lonchaeidae species and their hosts in the State of Bahia, Brazil and new bitrophic interactions.

In the following municipalities of the State of Bahia, Brazil: Barra do Choça (1444' S, 40²6’ W), Jiquiriçá (13 ${ }^{\circ} 16^{\prime}$ S, 39 $9^{\circ} 34^{\prime} \mathrm{W}$; $13^{\circ} 17^{\prime} \mathrm{S}, 39^{\circ} 34^{\prime} \mathrm{W}$ and $13^{\circ} 11^{\prime} \mathrm{S}$, $\left.39^{\circ} 33^{\prime \prime} \mathrm{W}\right)$, Laje $\left(13^{\circ} 13^{\prime} \mathrm{S}, 39^{\circ} 25^{\prime} \mathrm{W}\right)$, Planalto (13 $15^{\circ} \mathrm{S}$, $\left.39^{\circ} 43^{\prime} \mathrm{W}\right)$, Camamu (13 $58^{\prime} \mathrm{S}, 39^{\circ} 08^{\prime} \mathrm{W}$ and $13^{\circ} 58^{\prime} \mathrm{S}$, $\left.39^{\circ} 11^{\prime} \mathrm{W}\right)$ and Wenceslau Guimarães $\left(13^{\circ} 15^{\prime}\right.$ ' S, 39 $43^{\circ}$ ' W), from March 2013 through June 2015 were collected fruits belonging to 32 plants species and flower buds of yellow passion fruit, according to its availability in the crop fields. Fruits and flower buds were weighed, counted and displaced in plastic trays. After 12 days the pupae were conditioned in plastic pots containing vermiculite until the emergence of the adults that were preserved in plastic vials containing ethanol $70 \%$.

The adults males of Neosilba, Lonchaea and females of Dasiops were identified at species level utilizing a stereomicroscope and biological microscope (McAlpine and Steyskal, 1982; Norrbom and McAlpine, 1997).

From 11,320 pupae 5,821 adults emerged (5,549 specimens of Tephritidae, $95.3 \%), 232$ specimens of parasitoids (4.0\%) and 40 specimens of Lonchaeidae $(0.7 \%)$. Lonchaeidae infested 10 plant species: Spondias purpurea L. (Anacardiaceae), Rollinia sp. (Annonaceae), Carica papaya L. (Caricaceae), Averrhoa carambola L. (Oxalidaceae), Psidium guajava L., Syzygium malaccense (L.) Merr. \& L. M. Perry (Myrtaceae), Passiflora edulis f. flavicarpa Deg. (Passifloraceae), Coffea arabica L. (Rubiaceae), Citrus sinensis L. e Citrus aurantifolia L. (Rutaceae).
Neosilba glaberrima (Wiedmann, 1830) emerged from fruits of Rollinia sp., C. papaya, P. guajava e C. sinensis. Neosilba pendula (Bezzi, 1919) emerged from fruits of A. carambola, C. arabica, S. purpurea e S. malaccense and Neosilba zadolicha McAlpine \& Steyskal, 1982 emerged from fruits of Annonaceae, Passifloraceae e Rutaceae. Those species are considered to have the largest number of plant hosts among Neosilba species in Brazil and have a wide geographic distribution (Costa et al., 2009; Montes et al., 2010; Garcia and Norrbom, 2011; Strikis et al., 2011; Melo et al., 2012; Raga et al., 2015). Neosilba glaberrima $(n=6)$ was found attacking fruits of Annonaceae, Caricaceae e Myrtaceae and was for the first time associated to fruits of Rollinia sp. (Annonaceae).

Only one specimen of Neosilba certa (Walker, 1850) was found attacking fruit of $P$. guajava, trophic association already described by Souza-Filho et al. (2009) and in peach fruits by Montes et al. (2010) in the State of São Paulo, Brazil.

One specimen of Dasiops inedulis (Steyskal, 1980) emerged from flower bud of $P$. edulis f. flavicarpa. The same trophic relation was observed by Aguiar-Menezes et al. (2004) in the State of Espírito Santo and in Southern Bahia, both in Brazil, by Melo et al. (2012). Dasiops inedulis is considered an important pest of flowers buds of Passifloraceae, once the larvae feed on the ovaries of the flowers causing flower drop and the losses to the crop can reach $100 \%$ in commercial crops (Strikis et al., 2011).

In the present work new trophic relations were observed, like C. papaya x Lonchaea morphotype 1, Rollinia sp. $\mathrm{x}$ Neosilba glaberrima and C. arabica $\mathrm{x}$ Neosilba nigrocaerulea (Malloch, 1920). For the first time C. arabica is registered as host of Neosilba nigrocaerulea, which was found attacking fruits of Pouteria sp. (Sapotaceae) in the State of Amapá, Northern of Brazil (Strikis et al., 2011).

\section{References}

AGUIAR-MENEZES, E.L., NASCIMENTO, R.J. and MENEZES, E.B., 2004. Diversity of fly species (Diptera: Tephritoidea) from Passiflora spp. and their hymenopterous parasitoids in two municipalities of the Southeastern Brazil. Neotropical Entomology, 
vol. 33, no. 1, pp. 113-116. http://dx.doi.org/10.1590/S1519566X2004000100020.

COSTA, S.G.M., QUERINO, R.B., RONCHI-TELES, B., PENTEADO-DIAS, A.M.M. and ZUCCHI, R.A., 2009. Parasitoid diversity (Hymenoptera: Braconidae and Figitidae) on frugivorous larvae (Diptera: Tephritidae and Lonchaeidae) at Adolpho Ducke Forest Reserve, Central Amazon Region, Manaus, Brazil. Brazilian Journal of Biology $=$ Revista Brasileira de Biologia, vol. 69, no. 2, pp. 363-370. PMid:19675939. http://dx.doi.org/10.1590/ S1519-69842009000200018.

GARCIA, F.R.M. and NORRBOM, A.L., 2011. Tephritoid flies (Diptera, Tephritoidea) and their plant hosts from the state of Santa Catarina in southern Brazil. The Florida Entomologist, vol. 94, no. 2, pp. 151-157. http://dx.doi.org/10.1653/024.094.0205.

MCALPINE, J.F. and STEYSKAL, G.C., 1982. A revision of Neosilba McAlpine with a key to world genera of Lonchaeidae (Diptera). Canadian Entomologist, vol. 114, no. 2, pp. 105-137. http://dx.doi.org/10.4039/Ent114105-2.

MELO, E.A.S.F., SANTOS, E., ALMEIDA, F.R., ROCHA, R.B., SANTOS, O.O., STRIKIS, P.C. and BITTENCOURT, M.A.L., 2012. Hospedeiros, níveis de infestação e parasitoides de moscas frugívoras (Diptera: Tephritidae e Lonchaeidae) em municípios da região Sul da Bahia. Magistra, vol. 24, pp. 8-16.

MONTES, S.M.N.M., RAGA, A., BOLIANI, A.C., STRIKS, P.C. and SANTOS, P.C., 2010. Infestación natural de Lonchaeidae
(Diptera) en variedades de melocotón. Revista Colombiana de Entomologia, vol. 36, no. 2, pp. 223-228.

NORRBOM, A.L. and MCALPINE, J.F., 1997. A revision of the neotropical species of Dasiops Rondani (Diptera: Lonchaeidae) attacking Passiflora (Passifloraceae). Memoirs of the Entomological Society of Washington, vol. 18, no. 1, pp. 189-211.

RAGA,A., SOUZA-FILHO, M.F., STRIKIS, P.C. and MONTES, S.M.N.M., 2015. Lance fly (Diptera: Lonchaeidae) host plants in the State of São Paulo, Southeast Brazil. Entomotropica, vol. 30, no. 1, pp. 57-68.

SOUZA-FILHO, M.F., RAGA, A., AZEVEDO-FILHO, J.A., STRIKIS, P.C., GUIMARÃES, J.A. and ZUCCHI, R.A., 2009. Diversity and seasonality of fruit flies (Diptera: Tephritidae and Lonchaeidae) and their parasitoids (Hymenoptera: Braconidae and Figitidae) in orchards of guava, loquat and peach. Brazilian Journal of Biology $=$ Revista Brasileira de Biologia, vol. 69, no. 1, pp. 31-40. PMid:19347143. http://dx.doi.org/10.1590/S151969842009000100004 .

STRIKIS, P.C., DEUS, E.G., SILVA, R.A., PEREIRA, J.D.B., JESUS, C.R. and MASARO-JÚNIOR, A.L., 2011. Conhecimento sobre Lonchaeidae na Amazônia brasileira. In: R.A. SILVA, W.P. LEMOS and R.A. ZUCCHI, eds. Moscas-das-frutas na Amazônia Brasileira: diversidade, hospedeiros e inimigos naturais. Macapá: Embrapa Amapá, pp. 209-215. 